\title{
SOCIALINIO KAPITALO APIBRĖŽTIES IR MATAVIMO PROBLEMATIKA
}

\author{
Ilona Skačkauskiené $\dot{1}^{1}$, Sigita Bytauté ${ }^{2}$ \\ Vilniaus Gedimino technikos universitetas, Sauletekio al. 11, LT-10223 Vilnius, Lietuva \\ El. paštas: ${ }^{1}$ ilona.skackauskiene@vgtu.lt; ${ }^{2}$ sigita.bytaute@vgtu.lt
}

Iteikta 2012-03-16; priimta 2012-05-31

\begin{abstract}
Santrauka. Pasaulinė ekonomikos krizė skatina šalių vyriausybes ieškoti ne tik finansinio stabilizavimo priemonių, bet ir rasti „saugiklius“, kurie užkirstų kelią ekonominèms krizèms ateityje. Socialinis kapitalas galètų būti vienu tokių saugiklių. Straipsnyje, atlikus socialinio kapitalo apibrèžimų skirtinguose mokslinès literatūros šaltiniuose analizę, identifikuojamos matavimo problemos, atskleidžiamos sąsajos tarp socialinio kapitalo ir ekonominio vystymosi. Socialinis kapitalas yra sudètingas reiškinys, apimantis tokias tris dimensijas, kaip socialiniai tinklai, pasitikejimas ir socialinės normos. Sunkumų kyla siekiant ịvertinti kiekvienos iš dimensijų daugiareikšmiškumą: nėra vieno, universalaus socialinio kapitalo sąvokos apibrèžimo ir matavimo metodo, kuris galètų būti taikomas empiriniuose tyrimuose. Straipsnyje, išgryninus socialinio kapitalo komponentus, atskleidžiamas jo matavimo potencialas.
\end{abstract}

Reikšminiai žodžiai: socialinis kapitalas, pasitikejjimas, tinklai, rodikliai.

\section{SOCIAL CAPITAL DEFINITION AND MEASUREMENT PROBLEMS}

\section{Ilona Skačkauskiené $\dot{1}^{1}$, Sigita Bytaute ${ }^{2}$}

Vilnius Gediminas Technical University, Sauletekio al. 11, LT-10223 Vilnius, Lithuania

E-mails: ${ }^{1}$ ilona.skackauskiene@vgtu.lt; ${ }^{2}$ sigita.bytaute@vgtu.lt (correspondingauthor)

Received 16 March 2012; accepted 31 May 2012

\begin{abstract}
Global economic crisis encourages governments not only to look beyond financial stabilization measures, but also find the "safeguards" to prevent economic crises in the future. Social capital could be one of these "safeguards". In the paper analysis of social capital definition in different scientific literature is made, measurement problems are identified, the link between social capital and economic development is disclosed. Social capital is a complex phenomenon that includes the following three dimensions - social networks, trust and social norms. Difficulties arise while assessing ambiguity of each dimension: there is not a single, universal definition of social capital nor measurement method, which could be used in empirical studies. In the paper components of social capital are identified, the potential of its measurement is revealed.
\end{abstract}

Keywords: social capital, trust, networks, indicators.

JEL Classification: A12, A31, L14, P20, Z13. 


\section{Ivadas}

Ekonomikos krizė, apėmusi daugeli pasaulio valstybių, parodè, kad būtina ne tik pertvarkyti valstybių ekonominę bei finansinę politiką, bet ir ieškoti naujų priemonių, sudarančių galimybę išvengti krizių ateityje. Patikima priemone galètų tapti socialinis kapitalas - akivaizdu, kad ekonominé veikla integruojasi ị socialines struktūras, o žmonių sprendimams ịtaką daro begalè socialiniu ir kultūrinių veiksnių.

Socialinio kapitalo sąvoka paplitusi beveik visose socialinių tyrimų srityse ir yra vartojama aiškinant tokius reiškinius, kaip, pavyzdžiui, politinį dalyvavimą, institucinę veiklą, korupciją viešajame sektoriuje, viešųjų paslaugų kokybę ar valstybių ekonominę sèkmę (Sabatini 2005). Mokslininkai išplètojo socialinio kapitalo sąvoką siekdami paaiškinti skirtingą visuomenès gebëjimą veikti kolektyviai ir pasiekti bendrų tikslų. Noredami nustatyti abipusius tikslus ir bendradarbiauti juos iggvendinant, žmonès turi pasitikèti vieni kitais ir valdžios institucijomis, kurios savo ruožtu privalo užtikrinti minètam bendradarbiavimui palankią aplinką (Wallis et al. 2004).

Literatūroje pabrèžiamas ryšys tarp socialinio kapitalo ir ekonominès veiklos rezultatų. Socialiniai tinklai ir pasitikejjimas gali skatinti informacijos ir žinių sklaidą, sumažinti sandorių išlaidas. Empiriniais tyrimais įrodyta, kad socialinio kapitalo komponentai - pasitikejjimas ir visuomenès bendradarbiavimas - susiję su geresniais ekonominès veiklos rezultatais. Kaip panaudoti socialinị kapitalą, siekiant geresnių ekonominès veiklos rezultatų, analizuoja tokie mokslininkai, kaip Dasgupta ir Serageldin (2000), Grootaert ir Bastelaer (2002), Sabatini (2005).

Empirinių tyrimų rezultatų analizé parodè, kad socialinio kapitalo neįmanoma išmatuoti vienu rodikliu. Pagrindinè problema ta, kad literatūroje, nagrinëjančioje socialinį kapitalą, nẻra bendrų pasitikèjimo ar visuomenès bendradarbiavimo vertinimo rodiklių. Socialinis kapitalas nagrinejamas ivvairiais aspektais taikant skirtingus socialinio kapitalo matavimo rodiklius, todèl tyrimų rezultatai yra sunkiai tarpusavyje palyginami.

Straipsnyje nagrinėjamas socialinio kapitalo sąvokos turinys, atliekama socialinio kapitalo apibrèžimo skirtinguose moksliniuose šaltiniuose analizé, atskleidžiami socialinio kapitalo matavimo keblumai, akcentuojama socialinio kapitalo įtaka ekonomikai, t. y. išgryninamos sąsajos tarp socialinio kapitalo ir ekonominès veiklos rezultatų. Tyrimui taikytas sisteminis požiūris, mokslinès literatūros loginès analizès ir sintezès metodai.

\section{Socialinio kapitalo sąvokos evoliucija}

Mokslinès literatūros šaltiniuose pateikiami skirtingi ịvairiu darbų autorių požiūriai ị socialinị kapitalą (1 lentelè). Pirmą kartą XX a. pr. suformuluotoje socialinio kapitalo sąvokoje akcentuojama bendruomenès gerové, kuri pasiekiama per socialinị pavienių asmenų ir šeimų, sudarančių socialinį vie- netą, bendravimą (Hanifan 1916). Vèlesniuose apibrèžimuose akcentuojama žmonių grupès nariams teikiama kolektyvinè parama suteikiant teisę i šs̆ kapitalą ekonomine, kultūrine ar simboline šio žodžio prasme (Biggart 2002). Socialinio kapitalo potencialas priklauso nuo individualių ryšių, kuriuos asmuo gali efektyviai mobilizuoti, tinklo dydžio ir nuo kiekvieno tinklui priklausančio asmens kapitalo (ekonominio, kultūrinio ar simbolinio) (Bourdieu 1986). Socialinis kapitalas apibūdinamas kaip socialinių ryšių tinklas, kurị turi ir kuriuo naudojasi asmuo. Bourdieu (1986) akcentuoja, kad ne ryšiai savaime daro žmones turtingesnius arba skurdesnius, o tai, kas lemia tuos socialinius ryšius, kas juos valdo ir turi galią. Pavyzdžiui, bendruomenès gali turèti daug socialinio kapitalo, didelį narių pasitikèjimą, tačiau jei joms trūksta valdžios arba galių ir ekonominių išteklių, lieka tik bendruomeniškumo apraiškos. Anot Bourdieu, sąvokos „kapitalas" ir "galia“ yra sinonimai. Kapitalo - tiek kultūrinio, tiek ekonominio ar socialinio - atsiradimas, kūrimas ir didinimas yra iš esmės su galia, valdžia susijęs procesas. Tijūnaitienè (2008) teigia, kad socialinis kapitalas susiformuoja tada, kai sukuriamos sąlygos susibūrusiems tinklams kontroliuoti kapitalo srautus ir galios procesus. Nauda, kuri gaunama dèl narystès žmonių grupejje, tampa solidarumo pagrindu (Marginson 2004). Akivaizdus to ịrodymas - tikslingas išskirtinių klubų organizavimas siekiant sukoncentruoti socialinį kapitalą ir gauti iš to visapusę naudą dèl susidarančio multiplikatoriaus efekto. Be to, taip užsitikrinama narystès teikiama ir materialinè nauda - įvairių rūšių paslaugos, gaunamos dẻl naudingų ryšių, ir netiesioginè nauda, pavyzdžiui, dèl sąsajų su reta, prestižine grupe (Biggart 2002). Bet koks savaime susikūręs socialinis tinklas nelaikomas gebančiu telkti reikšmingus išteklius ir generuoti galią.

Putnam (2000) suformulavo socialinio kapitalo kaip siejamojo (angl. bonding) arba jungiamojo (angl. bridging) veiksnio sampratą. Siejamieji socialiniai tinklai atsiranda tarp panašios kilmės, religijos, rasės, etniškumo, socialinès klasès žmonių. Jungiamieji socialiniai tinklai sujungia skirtingos kilmès ar religijos, rasės, etniškumo ar socialinès klasės žmones. Tokie siejamieji ar jungiamieji tinklai gali paskatinti, pavyzdžiui, ìdarbinimo, skolinimosi jungčių susidarymą (Eastwood 2009). Ryšiai su panašiais arba artimais žmonèmis (siejamieji tinklai) padeda žmonèms išgyventi, o ryšiai su žmonèmis, besiskiriančiais pagal socialiniame gyvenime svarbius požymius (jungiamasis tinklas), padeda judèti ị priekị, kažką keisti gyvenime (Žiliukaitè 2004). Pažymètina, kad Putnam kaip socialinio kapitalo naudojimo rezultatą išskyrẻ kolektyvinị produktyvumą, tuo suteikdamas šiai sąvokai naują - ekonomini - aspektą. Putnam teigimu, socialinis kapitalas, kyląs iš dalyvavimo visuomeninėse organizacijose ir savanoriškoje veikloje, atlieka tokias funkcijas, kaip demokratiško valdymo ir ekonominio augimo skatinimas bei palaikymas.

Ekonomistų demesį socialiniam kapitalui paskatino ir Pasaulio bankas, kuris 1996 m. pradèjo Socialinio kapitalo iniciatyvą (The Social Capital Initiative), siekdamas îvertinti 
1 lentelè. Socialinio kapitalo apibrěžimų įvairovė (sudaryta autorių)

Table 1. Variety of social capital definitions (compiled by the authors)

\begin{tabular}{|c|c|}
\hline Autorius & Socialinio kapitalo apibrèžimas \\
\hline Hanifan (1916) & $\begin{array}{l}\text { Apčiuopiamos materijos, kurios svarbios kasdieniame žmogaus gyvenime: gera valia, draugystė, } \\
\text { simpatija ir socialinis bendravimas tarp asmenų ir šeimų, sudarančių socialinị vienetą. Jeigu } \\
\text { asmuo palaiko ryšį su kaimynais, o šie - su kitais kaimynais, tai bus socialinio kapitalo kaupimas, } \\
\text { kuris gali patenkinti asmens socialinius poreikius ir skleidžia socialinị potencialą, pakankamą } \\
\text { visos bendruomenès gyvenimo sąlygoms pagerinti. }\end{array}$ \\
\hline Bourdieu (1986) & $\begin{array}{l}\text { Visuma esamų ir potencialių išteklių, siejamų su tvirtu institucionalizuotų tarpusavio pažinimo ar } \\
\text { pripažinimo santykių tinklu. }\end{array}$ \\
\hline Pasaulio bankas (1996) & Tai normos ir tinklai, kurie skatina kolektyvinę veiklą. \\
\hline Putnam (2000) & $\begin{array}{l}\text { Ryšiai tarp individų bei iš to kylantys socialiniai tinklai ir abipusiškumo bei pasitikejimo normos. } \\
\text { Socialinis kapitalas gali būti siejamasis (panašios kilmės, religijos, rasės, etniškumo, socialinės ir } \\
\text { ekonominès klasès asmenys) arba jungiamasis (skirtingos kilmès ar religijos, rasès, etniškumo ar } \\
\text { socialinès ir ekonominès klasès asmenys. }\end{array}$ \\
\hline Fukuyama (2001) & $\begin{array}{l}\text { Neformali, socialiniuose ryšiuose ịkūnyta norma, kuri skatina bendradarbiavimą tarp dviejų ar } \\
\text { daugiau asmenų. }\end{array}$ \\
\hline Acevedo (2007) & Sanglaudos priemonė ir vienas iš visuomenės gerovės rodiklių. \\
\hline
\end{tabular}

socialinio kapitalo įtaką plètros (vystymo) projektų efektyvumui bei prisidèti prie socialinio kapitalo stebejjimo rodiklių ir socialinio kapitalo įtakos vertinimo metodologijos sukūrimo (Grootaert, Bastelaer 2001). Putnam pateiktas socialinio kapitalo apibrěžimas Pasaulio banko ekspertams tapo „trūkstama grandimi“. Neatsitiktinai tiek Pasaulio banko, tiek Putnam suformuluotuose socialinio kapitalo apibrèžimuose akcentuojami socialiniai tinklai bei normos.

Fukuyama (2001) pabrèžia, kad visos socialinị kapitalą turinčios grupès spinduliuoja tam tikru pasitikejjimu, t. y. tame suburtame asmenų rate geranoriškas bendradarbiavimas yra tapęs norma. Pasitikejjimas sudaro prielaidas didinti grupès ar organizacijos veiklos veiksmingumą. Be to, šis autorius pabrèžè ekonominị socialinio kapitalo aspektą - socialinio kapitalo naudojimas leidžia sumažinti su formaliais koordinavimo mechanizmais susijusių sandorių sąnaudas.

Acevedo (2007) akcentuoja socialinị kapitalą kaip socialinès sanglaudos priemonę, kuri ypač svarbi visos žmonijos vystymuisi. Dalyvavimu, pasitikejjimu, solidarumu pagrịstas supratimas, įsipareigojimai yra būtini siekiant gero valstybès valdymo bei pilietiškumo.

Galima teigti, kad socialinis kapitalas yra visuma ryšių ir bendrų vertybių, sukurtų ir naudojamų kolektyvinèms ar individualioms problemoms spręsti. Jis atspindi kultūrines, normatyvines, struktūrines ir institucines įvairaus dydžio žmonių grupių tarpusavio sąveikas. Socialinis kapitalas taip pat apibūdina galimą šių sąveikų ittaką individualioms iniciatyvoms ir elgesiui bei jų sukeltus ekonominius, politinius ir kitus pokyčius (Bartkus, Davis 2009).

Mokslinès literatūros šaltiniuose išskiriami trys pagrindiniai socialinio kapitalo komponentai: pasitikejjimas, pilietinio angažuotumo tinklai ir normos bei vertybès. Pasitikèjimas yra esminis socialinio kapitalo komponentas. Bendras veikimas pamažu sukuria tam tikras moralines sankcijas, kurios taikomos pažeidus pasitikèjimą. Socialinị pasitikèjimą visuomenèje didina valdžios institucijų veiklos viešumas, valdininkų veiklos etika. Socialinis kapitalas sudaro prielaidas formuotis ir pilietinei visuomenei, kuri savo ruožtu yra žinių ekonomikos dalyvė ir pokyčių bei inovacijų katalizatorius (Tijūnaitienè 2008).

Dalyvavimas bendruomenių, visuomeninių organizacijų veikloje yra svarbus tiek pilietiškumo, moralès formavimuisi, tiek bendradarbiavimo îpročiams susidaryti (Tijūnaitienė 2008). Taigi pilietinio angažuotumo tinklai yra kitas socialinio kapitalo komponentas, apimantis nevyriausybinių organizacijų sektorių. Kuo šie tinklai bendruomenėse tankesni, tuo, Putnam (2000) įsitikinimu, didesnè tikimybè, kad jos piliečiai sugebès veikti bendros naudos labui.

Trečiasis socialinio kapitalo komponentas - normos ir vertybės - apima ịvairius viešojo socialinio gyvenimo aspektus, tokius kaip savitarpio pagalba, socialumas, dalyvavimas, altruizmas. Nagrinejjant socialinio kapitalo susidarymo būdus, išskirtinis demesys skiriamas bendravimui - bendraujant visuomeneje susiformuoja normos ir tradicijos, kuriomis remdamiesi žmonès buriasi i grupes (Juozaitienè 2006). Tokiose socialinèse grupèse ir atsiranda minètas pasitikejimas - esminis socialinio kapitalo bruožas, skatinantis veikti net ir tada, kai nèra išsamios informacijos apie partnerių patikimumą. Dalyvavimas įvairių grupių veiklose, naujų poreikių formavimas tampa svarbiu visuomenès permainų katalizatoriumi. Galima teigti, kad dalyvavimas ivvairiose veiklose lemia ir socialinio kapitalo augimą, be to, socialinio kapitalo „auginimas“ gali padèti kuriant valstybès socialinę politiką. 
Kadangi bet koks verslo sandoris yra daugiau ar mažiau grindžiamas pasitikejjimu, akivaizdi socialinio kapitalo ir ekonomikos sąveika: daugiau investuojama tose šalyse, kuriomis labiau pasitikima, arba tose šalyse, kur tikimasi gauti daugiau pelno (Deveikis, Poviliūnas 1998). Taigi socialinis kapitalas arba pasitikejjimas, kaip vienas pagrindiniu socialinio kapitalo komponentų, sudaro prielaidas ūkio plètrai. Socialinis kapitalas, kilęs iš dalyvavimo visuomeninèse organizacijose ir savarankiškoje veikloje, skatina demokratišką valdymą, aktyvina ir palaiko ekonominị augimą bei plètrą (Putnam 2000).

Pažymètina, kad literatūroje diskutuojama dèl termino „kapitalas“, ịeinančio ị sąvoką „socialinis kapitalas“, vartojimo. Anot ekonominès srities mokslininkų, šio termino vartojimas tokiame kontekste netinkamas, nes kapitalas siejamas su nuosavybe (daiktais, kuriuos galima valdyti). Pavyzdžiui, Bowles ir Gintis (2002) pasiūlè kaip tinkamesnị terminą „bendruomenë“, taip didesnị dèmesị skiriant tam, ką grupès veikia, o ne ką jos turi, taip tiksliau atspindint gero valdymo, paaiškinančio socialinio kapitalo populiarumą, aspektus. Pasak autorių, „bendruomenë“ yra tiesiogiai, dažnai įvairiapusiškai sąveikaujančių asmenų grupè. Šią mintị pabrèžia ir Arrow, kurio manymu, „kapitalas“ yra tai, kas gali būti „nusavinta“ - nuosavybès teise vieno asmens perduodama kitam asmeniui. Socialinio, kaip ir žmogiškojo, kapitalo nuosavybę, pakeisti yra sudètinga (Sabatini 2006). Portes (2007) teigimu, ekonominis kapitalas yra žmonių sąskaitose banke, žmogiškasis kapitalas - jų galvose, o socialinis kapitalas glūdi žmonių santykių struktūrose. Norint igyti socialinị kapitalą, būtina palaikyti ryšius su kitais asmenimis, kurie ir yra tikrieji ryšius palaikančiojo asmens naudos šaltiniai. Coleman (1990) akcentuoja, kad socialinis kapitalas, kaip socialinès struktūros, kuriai asmuo priklauso, atributas nėra nuosavybè to, kuris iš jo gauna naudą. Socialinis kapitalas egzistuoja tik tuomet, kai yra bendrai naudojamas. Apibendrinant šią diskusiją, galima teigti, kad termino „kapitalas“vartojimas junginyje „socialinis kapitalas" yra priimtinas ir tinkamas, taip pat kaip ir įsitvirtinusio termino „žmogiškasis kapitalas“ atveju. Žinoma, socialinis kapitalas yra mažiausiai apčiuopiamas, palyginti su materialiuoju ir žmogiškuoju kapitalu, tačiau jis taip pat skatina ūkio plètrą, juo siekiama tobulinti visuomenès gebejjimus. Terminas „kapitalas“ reiškia ne tik „turèjimą“, bet ir vertę, o socialiniai tinklai, kaip minèta, kuria ekonominę ir socialinę vertę, atneša materialinę ir nematerialinę naudą tokių tinklų dalyviams.

Diskusijos dèl socialinio kapitalo sujungè sociologijos, antropologijos, politikos, ekonomikos ir vadybos mokslu atstovus. Ir nors nuomonių skirtumai išlieka, sutariama dẻl to, kad socialinis kapitalas unikalus savo santykių aspektu. Aktyvus mokslininkų ir praktikų domèjimasis pastūmèjo šią sritị i priekị tiek konceptualaus vystymosi, tiek empirinių rezultatų prasme. Taigi pagrindinè šio termino vartojimo prasmė yra socialinių santykių akcentavimas (Narayan 1999).

\section{Socialinio kapitalo matavimo galimybių analizè}

Socialinis kapitalas, reiškiantis aktyvų visuomenės narių dalyvavimą ịvairiose bendruomeninèse organizacijose, klubuose, partijose, rinkimuose, domejjimąsi šalies ir pasaulio ivykiais, iprastai yra matuojamas tokiais rodikliais, kaip šalies gyventojų priklausomybė įvairioms organizacijoms, dalyvavimas rinkimuose (aktyvumas), laikraščių skaitymas ir televizijos laidų žiūrèjimas. Vis dèlto socialinio kapitalo matavimas yra problemiškas. Sabatini (2006) išskyrè tokias pagrindines socialinio kapitalo matavimo problemas:

1) nepaisant daugybès atliktų tyrimų šia tema, socialinio kapitalo apibrèžimas vis dar išlieka aptakus ir tai lemia jo matavimo sudètingumą;

2) socialinio kapitalo sąvoka yra daugiamatè, todèl kiekvienas tyrejjas pasirenka skirtingą sąvokos aspektą, atsi-

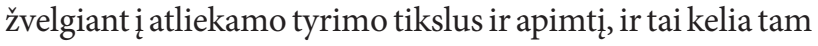
tikrą painiavą lyginant tyrimų rezultatus;

3) socialiniam kapitalui vertinti naudojant vis kitus rodiklius, tokius kaip nusikalstamumo lygis, paauglių néštumas, kraujo donoryste, dalyvavimo trečiosios pakopos studijose lygis, innešè painiavą suvokiant ryšį tarp socialinio kapitalo ir jo buvimo ar nebuvimo pasekmių;

4) didžioji dalis atliktų socialinio kapitalo ir šalių ekonominio vystymosi ryšio nustatymo tyrimų remiasi pasaulio vertybiu tyrimuose taikomais pasitikejjimo vertinimo rodikliais. Šiuose tyrimuose pasitikejimas aiškinamas kaip asmens savo socialinès aplinkos suvokimas, atsižvelgiant $\mathfrak{i}$ užimamą padèti socialinèje struktūroje. Taigi empiriniai tyrimai, kurie remiasi tarpvalstybiniu pasitikejjimo palyginimu, gali nuvesti į aklavietę, nes neatsižvelgiama î platesnị nuostatų formavimosi ir apibrèžimo kontekstą bei atitinkamai nesugebama tinkamai ịvertinti pasekmių makrolygiu;

5) tyrimuose, kuriuose akcentuojami socialiniai tinklai, skiriama nepakankamai demesio daugiamačiam, nuo konteksto priklausančiam, dinamiškam socialinio kapitalo pobūdžiui. Dèmesio sutelkimas ị vienos rūšies tinklą lemia neatitikimus imtyje, kurie savo ruožtu kelia pavojų tyrimų rezultatų objektyvumui ir išvadoms;

6) nors daugelyje tyrimų savanoriškos visuomeninès organizacijos yra svarbus socialinio kapitalo vertinimo rodiklis, išlieka abejonių dèl socialinio kapitalo vertinimo savanoriškų organizacijų tankio pagrindu efektyvumo: ne visos visuomeninès organizacijos vykdo aktyvią veiklą neretai apsiribojama formaliu egzistavimu.

Nevienareikšmiškas socialinio kapitalo apibrèžimas (iš esmès bet kokia socialinė sąveika gali būti traktuojama kaip socialinis kapitalas) lemia ir jo matavimo daugialypumą. Susisteminti socialinio kapitalo tyrimai ir jų rezultatai pateikti 2 lenteleje. Žinomiausias šių tyrimų pavyzdys - Putnam studija, atlikta $1993 \mathrm{~m}$. dvidešimtyje Italijos provincijų. Mokslininkas lygino regionų ekonominius, socialinius, institucinius skirtumus. Panašią studiją $2000 \mathrm{~m}$. Putnam atliko Jungtinèse Amerikos Valstijos (JAV): tirta ir lyginta atskirų valstijų kriminogeninė situacija, gyventojų sveikata, išsimokslinimas ir jų ryšys su socialiniu kapitalu. 
2 lentelè. Socialinio kapitalo tyrimai ir jų rezultatai (sudaryta autorių)

Table 2. Social capital studies and their results (compiled by the authors)

\begin{tabular}{|c|c|c|c|}
\hline \multirow{6}{*}{ : } & Tyrèjai & Tyrimo turinys & Tyrimo rezultatai \\
\hline & $\begin{array}{l}\text { S. Knack ir } \\
\text { P. Keefer (1997) }\end{array}$ & $\begin{array}{l}\text { Tirtos pasirinktos } 29 \text { rinkos ekonomikos } \\
\text { šalys. Tyrimo metu taikyti Pasaulio } \\
\text { vertybių tyrimuose (PVT) naudojami } \\
\text { pasitikejjimo ir pilietinių normų rodikliai. }\end{array}$ & $\begin{array}{l}\text { Pasitikèjimas ir pilietinès normos yra stipresnès } \\
\text { tose tautose, kuriose aukštesnès pajamos, } \\
\text { valstybės institucijos pažaboja neteisètus valdžios } \\
\text { atstovų veiksmus ir kurių visuomenès yra labiau } \\
\text { išsilavinusios bei etniškai homogeniškos. }\end{array}$ \\
\hline & $\begin{array}{l}\text { D. Narayan } \\
\text { ir L. Pritchett } \\
(1997)\end{array}$ & $\begin{array}{l}\text { Socialinis kapitalas vertintas vadovaujantis } \\
\text { Tanzanijos socialinio kapitalo ir skurdo } \\
\text { tyrimo (SKST) surinktais duomenimis. } \\
\text { Ieškota sąsajų tarp pajamų dydžio ir } \\
\text { socialinio kapitalo lygio. }\end{array}$ & $\begin{array}{l}\text { Sukurtas socialinio kapitalo Tanzanijos kaimo } \\
\text { vietovėse vertinimo rodiklis. Irodyta, kad } \\
\text { socialinis kapitalas didina pajamas: namų ūkių } \\
\text { pajamos priklauso ne tik nuo individualaus namų } \\
\text { ūkio gebéjimų, bet ir nuo viso kaimo socialinio } \\
\text { kapitalo. }\end{array}$ \\
\hline & $\begin{array}{l}\text { J. S. Temple } \\
\text { ir P. Johnson } \\
(1998)\end{array}$ & $\begin{array}{l}\text { Matuotas socialinių tinklų tankis ị pietus } \\
\text { nuo Sacharos esančiose Afrikos šalyse. } \\
\text { Taikyti etninės vienovės, socialinio } \\
\text { mobilumo, telefono ryšio prieinamumo } \\
\text { rodikliai. }\end{array}$ & $\begin{array}{l}\text { Naudojant agreguotą „socialinių gebejjimų“ rodiklị } \\
\text { aiškinami reikšmingi nacionalinès ekonomikos } \\
\text { augimo tempų skirtumai. }\end{array}$ \\
\hline & $\begin{array}{l}\text { J. Onyx ir } \\
\text { P. Bullen (2000) }\end{array}$ & $\begin{array}{l}\text { Vykdant socialinio kapitalo tyrimus } \\
\text { Australijoje, apklausta } 1200 \text { respondentų } \\
\text { iš kaimo ir miesto bendruomenių. Taikyti } \\
\text { Putnam ir Coleman pasiūlyti tinkliškumą, } \\
\text { savitarpio pagalbą, pasitikejjimą, socialines } \\
\text { normas, bendruomenes apibūdinantys } \\
\text { rodikliai. }\end{array}$ & $\begin{array}{l}\text { Tinkliškumas, pasitikèjimas ir socialinis } \\
\text { aktyvumas yra esminès sąlygos socialinio } \\
\text { kapitalo formavimuisi ir vystymuisi. Savitarpio } \\
\text { pagalba svarbi kaip trumpalaikis altruizmas } \\
\text { siekiant savo asmeninių tikslų ilgalaikejje } \\
\text { perspektyvoje. Socialinės normos nepriskirtos } \\
\text { prie esminių kintamųjų, tačiau svarbios kaip } \\
\text { bendrasis kintamasis, ypač kalbant apie asmenų } \\
\text { polinki padèti artimui, tarpininkauti, dalyvauti } \\
\text { bendruomeniniuose projektuose, pasitiketi } \\
\text { vieniems kitais. }\end{array}$ \\
\hline & $\begin{array}{l}\text { A. Krishna, } \\
\text { N. Uphoff } \\
(1999)\end{array}$ & $\begin{array}{l}\text { Radžastane (Indija) vertintas socialinio } \\
\text { kapitalo vaidmuo gerinant vietinių } \\
\text { ekonominio vystymo iniciatyvų } \\
\text { efektyvumą, didžiausią demesị skiriant } \\
\text { vandenskyros plètros ir skurdo mažinimo } \\
\text { projektams regione. Atmestas formalių } \\
\text { organizacijų tankumo rodiklis kaip ypač } \\
\text { netinkamas Radžastano kaimams. }\end{array}$ & $\begin{array}{l}\text { Sudarytas rodiklių, akcentuojančių neformalius } \\
\text { tinklus, rinkinys ir akcentuota lyderių, galinčių } \\
\text { sutelkti socialinį kapitalą didesniam vystymo ir } \\
\text { plètros programų efektyvumui pasiekti, buvimo } \\
\text { svarba. Nustatyta, kad socialinio kapitalo } \\
\text { vertinimą svarbu sieti su skirtinga kultūrine, } \\
\text { socialine ir ekonomine aplinka. }\end{array}$ \\
\hline \multirow{4}{*}{ 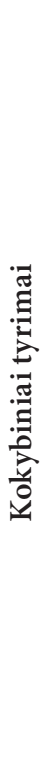 } & $\begin{array}{l}\text { R. D. Putnam } \\
(1993)\end{array}$ & $\begin{array}{l}\text { Tiriant Šiaurès ir Pietų Italijos socialinị } \\
\text { kapitalą pasirinkti aspektai: pilietinis } \\
\text { dalyvavimas, apimantis rinkejų aktyvumą, } \\
\text { laikraščių skaitomumas, narystė chorų } \\
\text { bendruomenėse ar futbolo klubuose, } \\
\text { pasitikejjimas valdžios institucijomis. }\end{array}$ & $\begin{array}{l}\text { Nustatyta, kad aukštas gyvenimo lygis Šiaurès } \\
\text { Italijoje susiformavo dèl plačių bendruomeninių } \\
\text { ryšių, kas visiškai nebūdinga uždarai Pietų Italijos } \\
\text { visuomenei, paremtai šeima ir „visų karu prieš } \\
\text { visus“, kai žmogus saugus jaučiasi tik šeimoje. } \\
\text { Socialinio kapitalo vystymas turejo lemiamą ịtaką } \\
\text { aukštesniam Šiaurès Italijos gyvenimo lygiui. }\end{array}$ \\
\hline & S. Gold (1995) & $\begin{array}{l}\text { Los Andžele, JAV, stebima žydų } \\
\text { bendruomenė. Tiriama, kaip kinta } \\
\text { bendruomenės ryšiai asimiliacijos svečioje } \\
\text { šalyje proceso metu. }\end{array}$ & $\begin{array}{l}\text { Itsitikinta, kad žydų bendruomenė asimiliuodamasi } \\
\text { išlaiko tiek bendruomenės struktūros vientisumą } \\
\text { (augina socialinị kapitalą), tiek aktyvų dalyvavimą } \\
\text { bendrajame ekonominiame gyvenime. }\end{array}$ \\
\hline & $\begin{array}{l}\text { Ch. J. Anderson } \\
\text { (1995) }\end{array}$ & $\begin{array}{l}\text { Tirtas senolių (kaip socialinio kapitalo } \\
\text { auginimo šaltinio) varganose Afrikos ir } \\
\text { Amerikos bendruomenèse JAV vaidmuo. }\end{array}$ & $\begin{array}{l}\text { Pastebėta, kad pagarba tirtose bendruomenèse } \\
\text { senoliams nyksta, taip pat mažeja ir tyrinètų } \\
\text { bendruomenių ekonominis vystymasis. }\end{array}$ \\
\hline & $\begin{array}{l}\text { A. Palloni ir kt. } \\
(2001)\end{array}$ & $\begin{array}{l}\text { Matuojant socialinį kapitalą JAV, tirta } \\
\text { naujųjų ir senųjų migrantų tarpasmeninių } \\
\text { ryšių, grindžiamų giminyste, draugyste ar } \\
\text { bendra bendruomenine kilme, nauda. }\end{array}$ & $\begin{array}{l}\text { Migracijos atveju socialinis kapitalas tampa } \\
\text { naudinga priemone ieškant informacijos šaltinių } \\
\text { apie galimas darbo vietas, karjeros galimybes, } \\
\text { apgyvendinimą ir kitas būtinas pragyventi svečioje } \\
\text { šalyje materialines sąlygas. }\end{array}$ \\
\hline
\end{tabular}


Literatūroje (Social... 2001) socialinis kapitalas vertinimo tikslais analizuojamas trimis lygiais: makro-, mezo- ir mikro-. Makrolygmuo apima formalius visuomenès santykius ir struktūras, tokias kaip politinè santvarka, teisinè bazè, valdymo decentralizacijos lygis bei visuomenès dalyvavimas politikos formavime. Mezolygmuo ịvardijamas kaip socialinè struktūra, kuri palengvina asmeninę ir bendrą veiklą. Ši struktūra turi vertikalius ir horizontalius ryšius bei santykių hierarchiją. Mikrolygmeniui priskiriamos šeimos ekonominès bei sociokultūrinès charakteristikos ir individualūs veiksniai, tokie kaip asmenybès savybès, charakteris, kognityviniai gebejjimai, aktyvumas, motyvacija ir pan.

Galima teigti, kad socialinio kapitalo matavimo rodikliu pasirinkimas priklauso nuo lygmens, kuriame jis nagrinejjamas (Grootaert, Bastelaer 2001). Pavyzdžiui, namų ūkių ir bendruomenių (atitinkamai mikro- ir mezo-) lygmenimis socialini kapitalą siūloma vertinti tokiais sudètiniais rodikliais, kaip bendruomenès tinklai, dalyvavimo visuomeninèje veikloje pobūdis ir apimtis bei mainai tarp kaimynu (Grootaert 1998). Valstybès (makro-) lygmeniu analizuojant socialinio kapitalo ir ekonominio augimo bei plètros ryši, taikomi Putnam pasiūlyti rodikliai: dalyvavimas bendruomeninèse organizacijose, laikraščiu skaitomumas, rinkejų aktyvumas. Atlikęs tyrimus JAV, Putnam (2000) socialinio kapitalo vertinimo rodiklių rinkinị papildo nevyriausybinių organizacijų ir narystés jose rodikliu. Nors Putnam pasiūlyti socialinio kapitalo vertinimo rodikliai kritikuoti dèl to, kad neatsižvelgiama ị bendruomeninių organizacijų narių dalyvavimo intensyvumą ir išorinius priklausymo grupei aspektus (Wallis, Killerby, Dollery 2004), jie plačiai taikomi socialinio kapitalo tyrimuose. Fukuyama (2001) papildo Putnam pasiūlytą mezolygmens rodiklių rinkinị šiais kintamaisiais: grupių darna bei grupių teigiamos ir neigiamos išorinès savybès, tokios kaip pasitikejjimo ar nepasitikejjimo ribos. Kiti mokslininkai pateikè savas Putnam ir Fukuyama požiūrių interpretacijas, pavyzdžiui, Onyx ir Bullen (2000) sukūrè socialinio kapitalo matavimo modelį, kuris apima ryšius su darboviete, šeima, draugais, kaimynais, tolerancijos lygị ir pasitikejimą (Bartkus, Davis 2009).

Grootaert (2001) rodiklius, kurie buvo naudoti empiriniuose socialinio kapitalo tyrimuose, suskirste į dvi grupes: proksimalinius ir distalinius (3 lentelè). Proksimaliniai rodikliai atspindi socialinio kapitalo pagrindinių komponentų tokių kaip tinklai, pasitikejimas ir abipusiškumas - buvimą ar nebuvimą. Distaliniai rodikliai - tiesiogiai nesusije su socialinio kapitalo pagrindiniais komponentais, bet gali atskleisti papildomą informaciją apie socialinị kapitalą.

Galima teigti, kad literatūroje (Bourdieu 1986; Coleman 1990; Putnam 1993; Fukuyama 2001; Grootaert, Bastelaer 2001) socialinis kapitalas ịprastai apibrèžiamas kaip tinklai, pasižymintys pasitikèjimu ir abipusiškumu. Tokị daugelio darbų autorių pateikiamą apibrèžimą tikslinga išskirti i kelias dalis: tinklus, kuriuos galima struktūrizuoti ir ịvertin- ti kiekybiškai, ir pasitikejimą bei abipusiškumą (savitarpio pagalbą), kurių vertinimui galima taikyti tiek kiekybinius, tiek kokybinius tyrimų metodus.

\section{Socialinis kapitalas: sinerginis požiūris}

Pasaulio banko tarpdisciplininè socialinio kapitalo grupe (1996) suformulavo socialinio kapitalo sampratą, išskirdama tris jo taikymo atvejus:

1. Bendruomeninis požiūris (angl. communitarian view). Socialinis kapitalas šiuo požiūriu nagrinejjamas per vietinių šalies organizacijų - tokių kaip asociacijos, klubai, pilietinès iniciatyvos grupès - prizmę, o matuojamas grupių skaičiaus ir tankio rodikliais bendruomeneje. Bendruomeninis požiūris ịprastai taikomas analizuojant skurdo problemas, socialinių ryšių svarbą kovojant su skurdo rizika ir pažeidžiamumu.

2. Tinkliškumo požiūris, kurị taikant akcentuojami vertikalūs ir horizontalūs ryšiai tarp žmonių, santykiai organizacijos viduje bei tarp organizacijų. Šiuo požiūriu išskiriamos tokios pagrindinès socialinio kapitalo dimensijos: stiprūs siejamieji ryšiai tarp bendruomenès narių (ryšiai tarp panašių arba artimų individų) ir gležni jungiamieji bendruomenès išorès tinklai (ryšiai su žmonèmis, besiskiriančiais socialiniame gyvenime svarbiais požymiais). Tinkliškumo požiūriu bendruomenès charakterizuotos pagal tai, kiek jos apima abiejų iš paminètų dimensijų, o skirtingi šių dimensijų deriniai lemia visą pasekmių, siejamų su socialiniu kapitalu, spektrą. Ilgainiui, kintant bendruomenès narių gerovei, keičiasi išlaidų ir naudos, siejamos su siejimu ir jungimu (ang. bonding and bridging), ivertis.

3. Institucinis požiūris. Bendruomenès tinklų ir pilietinès visuomenès gyvybingumas daugiausia priklauso nuo politinès, teisinès ir institucinès aplinkos. Instituciniu požiūriu, socialinių grupių galimybè siekti kolektyvinių tikslų veikiama formalių, virš bendruomenès struktūrų funkcionuojančių institucijų, o tokios savybès, kaip aukštas „bendras pasitikèjimas“" (remiantis Pasaulio vertybių tyrimo matmenimis), atitinka aukščiausius ekonominio vystymosi rodiklius. Šis požiūris taip pat pabrěžia, kad valstybių ir verslo įmonių veiklos rezultatai priklauso nuo jų vidinès darnos, patikimumo, kompetencijų ir atskaitomybès visuomenei.

Woolcock ir Narayan (2000) papildè Pasaulio banko suformuluotus socialinio kapitalo sampratos aspektus pasiūlydami naują komponentą - sinergini požiūrị. Juo siekiama integruoti tinklų ir institucinị požiūrius. Nors sinerginio požiūrio pradžia siejama su ankstyvaisiais lyginamosios politinès ekonomijos ir antropologijos darbais, reikšmingus šios srities tyrimus atliko Evans, kuris nagrinejo Indijos, Meksikos, Rusijos, Pietų Korèjos ir Brazilijos atvejus, siekdamas nustatyti sąlygas, skatinančias vystymosi „sinergijas“: dinamiškus santykius valstybių biurokratinio aparato viduje ir tarp jų, taip pat santykius tarp valstybių 
3 lentelè. Socialinio kapitalo matavimo rodikliai (Grootaert, Bastelaer 2001)

Table 3. Indicators of social capital (Grootaert, Bastelaer 2001)

\begin{tabular}{|c|c|}
\hline Proksimaliniai rodikliai & Distaliniai rodikliai \\
\hline \multicolumn{2}{|c|}{ Horizontalios asociacijos } \\
\hline $\begin{array}{l}\text { Asociacijų ar vietinių institucijų skaičius ir tipas } \\
\text { Narystės vietinėse asociacijose tankis } \\
\text { Dalyvaujančiųjų priimant sprendimus skaičius } \\
\text { Asociacijų narių homogeniškumas } \\
\text { Asociacijos pajamos } \\
\text { Namų ūkių ir kaimų gyventojų pasitikejimo lygis } \\
\text { Pasitikèjimo valdžia lygis }\end{array}$ & $\begin{array}{l}\text { Pasitikejjimas profesinėmis sąjungomis } \\
\text { Bendruomeninės organizacijos masto suvokimas } \\
\text { Priklausomybė nuo paramos tinklų } \\
\text { Piniginių perlaidų dalis namų ūkių pajamose } \\
\text { Namų išlaidų dalis, tenkanti dovanoms ir pervedimams }\end{array}$ \\
\hline \multicolumn{2}{|c|}{ Pilietinè ir politinė visuomenè } \\
\hline $\begin{array}{l}\text { Pilietinès laisvės indeksas } \\
\text { Gyventojų dalis, patirianti politinę diskriminaciją } \\
\text { Politinès diskriminacijos intensyvumo indeksas } \\
\text { Ekonominės diskriminacijos intensyvumo indeksas } \\
\text { Gyventojų dalis, dalyvaujanti separatistiniuose judejimuose } \\
\text { Gastil politinių teisių indeksas } \\
\text { Politinių laisvių („Freedom House“) indeksas }\end{array}$ & $\begin{array}{l}\text { Demokratijos indeksas } \\
\text { Korupcijos indeksas } \\
\text { Valdžios neveiksmingumo rodyklè } \\
\text { Demokratinių institucijų stiprumas } \\
\text { Žmogaus laisvių rodiklis } \\
\text { Politinio stabilumo rodiklis } \\
\text { Valdymo decentralizacijos laipsnis } \\
\text { Rinkejų aktyvumas } \\
\text { Politinių žmogžudysčių skaičius } \\
\text { Konstitucinės valdžios kaita } \\
\text { Perversmų skaičius }\end{array}$ \\
\hline \multicolumn{2}{|c|}{ Socialinè integracija } \\
\hline $\begin{array}{l}\text { Socialinio mobilumo rodiklis } \\
\text { Socialinès ịtampos rodiklis } \\
\text { Etnolingvistinè fragmentacija } \\
\text { Riaušès ir protesto demonstracijos } \\
\text { Streikai } \\
\text { Žmogžudysčių skaičius } \\
\text { Savižudybių skaičius }\end{array}$ & $\begin{array}{l}\text { Kitų nusikaltimų lygis } \\
\text { Kalinių skaičius, tenkantis } 100000 \text { gyventojų } \\
\text { Neteisètų veiksmų apimtys } \\
\text { Vaikų, augančių šeimoje su vienu iš tėvų, skaičius } \\
\text { Skyrybų skaičius } \\
\text { Jaunimo nedarbo lygis }\end{array}$ \\
\hline \multicolumn{2}{|c|}{ Teisiniai ir valdymo aspektai } \\
\hline $\begin{array}{l}\text { Biurokratijos kokybe் } \\
\text { Teismų sistemos nepriklausomybe் } \\
\text { Nusavinimo ir nacionalizacijos rizika }\end{array}$ & $\begin{array}{l}\text { Valdžios atsisakymo vykdyti įsipareigojimus pagal sutartis } \\
\text { skaičius } \\
\text { Vykdytinų sutarčių skaičius } \\
\text { Sutartyse numatytų pervesti lèšų sumos }\end{array}$ \\
\hline
\end{tabular}

biurokratinio aparato ir skirtingu pilietinès visuomenès veikejų. Šios studijos leido padaryti tokias išvadas:

1. Nei valstybè, nei visuomenè nèra savaime gera ar bloga; valdžios institucijos, korporacijos ir pilietinès grupès yra „kintamieji“ savo ịtakos kolektyvinių tikslų pasiekimui prasme.

2. Valstybè, verslas ir bendruomenès turi veikti išvien, bendradarbiauti vienas kitą papildydami idant būtų pasiekta ir skatinama tvari plètra. Taigi pagrindinè vystymosi teorijos ir praktikos užduotis būtų nustatyti sąlygas, kuriomis šios sinergijos susidaro (arba nesusidaro).

3. Valstybė, lyginant su kitais sektoriais, vaidina svarbiausią vaidmenị sudarydama sąlygas teigiamiems vystymosi rezultatams pasiekti. Valstybè yra ne tik galutinis viešųjų gèrybių (visuomenès sveikatos, visuotinio švietimo) tiekèjas ir galutinis teisinès valstybès (nuosavybès teisių, tinkamo teismo pro- ceso, žodžio laisvès) igyvendintojas ir arbitras, bet ir veikejjas, turintis geriausias pozicijas užtikrinant ilgalaikes sąsajas tarp skirtingų visuomenès klasių, etninių grupių, skirtingos rasès, lyties, politinių ir religinių pažiūrų visuomenès grupių. Bendruomenès ir verslas savo ruožtu yra svarbūs pripažįstant ir skatinant gerą valdžios vadovavimą. Sudètingoje institucinëje aplinkoje bendruomenès lyderiai, galintys ịsitraukti į efektyvią veiklą valstybès viduje, tampa bendresnių reformų vykdytojais (Fox 1992).

Pagrindiniai skirtumai tarp išskirtų požiūrių yra analizès objektas, t. y. ar socialinis kapitalas traktuojamas kaip nepriklausomas, priklausomas ar tarpinis kintamasis (4lentelè), ir tai, kokia apimtimi integruojami bendruomeninių tinklų ir instituciniai požiūriai. Reikšmingiausi darbai atlikti remiantis tinklų ir institucinėmis perspektyvomis, o Woolcock ir Narayan darbuose sintezės siekiama naujausiu, sinerginiu, požiūriu. 
4 lentelè. Keturi socialinio kapitalo požiūriai: pagrindiniai veikèjai ir politikos modeliai (Woolcock, Narayan 2000)

Table 4. Four approaches to social capital: key players and policy models (Woolcock, Narayan 2000)

\begin{tabular}{|c|c|c|}
\hline Požiūris & Pagrindiniai veikèjai & Politikos modeliai \\
\hline $\begin{array}{l}\text { Bendruomeninis požiūris } \\
\text { Vietinės asociacijos }\end{array}$ & $\begin{array}{l}\text { Bendruomeninės grupès } \\
\text { Savanoriškasis sektorius }\end{array}$ & $\begin{array}{l}\text { „Mažai yra gražu“ } \\
\text { Pripažinti socialinius neturtingųjų turtus }\end{array}$ \\
\hline $\begin{array}{l}\text { Tinklų požiūris } \\
\text { Vidiniai (siejamieji) ir tarpusavio } \\
\text { (jungiamieji) bendruomeniniai ryšiai }\end{array}$ & $\begin{array}{l}\text { Verslininkai } \\
\text { Verslo grupės } \\
\text { „Informacijos brokeriai“ }\end{array}$ & $\begin{array}{l}\text { Decentralizacija } \\
\text { Verslo zonų sukūrimas } \\
\text { Socialinių skirtumų sujungimas (angl. bridging) }\end{array}$ \\
\hline $\begin{array}{l}\text { Institucinis požiūris } \\
\text { Politinès ir teisinès institucijos }\end{array}$ & Privatus ir viešasis sektorius & $\begin{array}{l}\text { Pilietinių ir politinių laisvių suteikimas } \\
\text { Skaidrumas, atskaitomybė }\end{array}$ \\
\hline $\begin{array}{l}\text { Sinerginis požiūris } \\
\text { Bendruomeniniai tinklai ir valstybès } \\
\text { bei visuomenès santykiai }\end{array}$ & $\begin{array}{l}\text { Bendruomeninės grupės, pilietinè } \\
\text { visuomené, verslas, valstybės }\end{array}$ & $\begin{array}{l}\text { Bendra gamyba, papildomumas } \\
\text { Dalyvavimas, sąsajos } \\
\text { Vietinių organizacijų didinimas }\end{array}$ \\
\hline
\end{tabular}

Anot Woolcock ir Narayan (2000), taikant sinergini požiūrị tyrejjams ir politikos formuotojams iškyla trys pagrindinès užduotys:

1. Identifikuoti socialinių santykių, charakterizuojančių konkrečią bendruomenę, jos formalias institucijas bei jų tarpusavio sąveiką, pobūdį ir aprèptị.

2. Sukurti institucines strategijas, paremtas šių socialinių santykių supratimu, ypač atsižvelgiant į visuomenès ar bendruomenès siejamojo (angl. bonding) ar jungiamojo (angl. bridging) socialinio kapitalo apimti.

3. Nustatyti būdus ir priemones, kuriomis teigiamos socialinio kapitalo apraiškos - platus bendradarbiavimas, pasitikejjimas, institucinis našumas - gali pakeisti ir (arba) būti sukurtos iš neigiamų jo apraiškų, tokių kaip sektantiškumas, izoliuotumas, korupcija.

Sinerginis socialinio kapitalo požiūris sudaro prielaidas keisti situacijas, kuriose bendruomenių priešiškumas ir abejingumas paverčiamas efektyviu jų narių bendradarbiavimu.

\section{Išvados}

Per pastaruosius kelis dešimtmečius išaugęs dėmesys socialiniam kapitalui diskusijose apie pasaulio šalių ekonomini augimą ir vystymąsi suponuoja būtinybę išnagrinèti tiek patị sąvokos turinį, tiek galimą jo įtaką visuomenès ekonominei gerovei. Socialinis kapitalas apima bendruomeniu gebejjimus veikti kartu siekiant savo tikslų. Mokslineje literatūroje pasiektas konsensusas, kad socialinis kapitalas yra sudètingas reiškinys, apimantis tokias tris dimensijas, kaip socialiniai tinklai, pasitikèjimas ir socialinès normos.

Susisteminus mokslinès literatūros šaltiniuose pateikiamų socialinio kapitalo apibrěžimų ir jo matavimo būdų įvairovę, tikslinga skirti du socialinio kapitalo komponentus: tinklus, kuriuos galima struktūrizuoti ir ịvertinti kiekybiškai, ir pasitikejimą bei abipusiškumą (savitarpio pagalbą), kuriems vertinti taikytini tiek kiekybiniai, tiek kokybiniai tyrimų metodai.
Pagrindinės sąlygos, skatinančios valstybių ir jų ekonominio vystymosi sinergiją, t. y. dinamiškus santykius valstybių biurokratinio aparato viduje ir tarp ju, taip pat santykius tarp valstybių biurokratinio aparato ir skirtingu pilietinès visuomenès veikèjų, yra aktyvus valstybès, verslo ir bendruomenių bendradarbiavimas. Valstybė yra reikšmingas veikejjas, darantis ittaką ilgalaikių sąsajų tarp skirtingų visuomenès klasių, etninių grupių, lyčių, politinių ir religinių visuomenès grupių, buvimui. Todèl valstybè turètų kurti institucines strategijas, paremtas socialinių santykių supratimu, atsižvelgiant ị visuomenès susiejančio ir sujungiančio socialinio kapitalo dimensijas ir transformuoti situacijas, kuriose visuomenès socialinis kapitalas pakeičia silpnas, priešiškas ar abejingas formalias institucijas ị tas, kuriose šios dvi dimensijos papildo viena kitą.

Socialinis kapitalas, turintis tiesioginę įtaką ekonominiams procesams, yra puikus instrumentas veikti pastaruosius procesus be diskretinių ịsikišimo priemonių. Siekiant nustatyti efektyvius poveikio būdus ir priemones, būtini tolesni socialinio kapitalo ir ekonominių procesų sąveikos tyrimai.

\section{Literatūra}

Acevedo, M. 2007. Network Capital: an Expression of Social Capital in the Network Society, The Journal of Community Informatics [žiūrèta 2012-01-15]. Prieiga per internetą: http:// ci-journal.net/index.php/ciej/article/view/267/317

Anderson, Ch. J. 1995. Blaming the Government: Citizens and the Economy in Five European Democracies. Armonk: M. E. Sharpe, paper. ISBN 978-1-56324-448-3.

Bartkus, O. V.; Davis, J. H. (Eds.). 2009. Social Capital - Reaching Out, Reaching. Published by Edward Elgar Publishing Limited, UK. $347 \mathrm{p}$.

Biggart, N. W. (Ed.). 2002. Readings in Economic Sociology. Copyright Blackwell Publishers Ltd, Malden, Massachusetts, USA. 286 p. 
Bourdieu, P. 1986. The Forms of Capital, in Richardson, J. G.; Bourdieu, P. (Eds.). Handbook of Theory and Research for the Sociology of Education. New York: Greenwood Press, 241-248.

Bowles, S.; Gintis, H. 2002. Social capital and community governance, The Economic Journal 112(483): F419-F436. http://dx.doi.org/10.1111/1468-0297.00077

Coleman, J. S. 1990. Foundations of Social Theory. The Belknap Press of Harvard University Press, London, 304-318.

Dasgupta, P.; Serageldin, I. (Eds.). 2000. Social Capital: a Multifaceted Perspective. Washington, DC: The World Bank, 13-45.

Deveikis, L.; Poviliūnas, A. 1998. Žmogaus teise ir pilietine visuomene. Vilnius: Margi raštai, 43-44.

Eastwood, B. M. 2009. Creative class vs. Social capital vs. economic freedom: U.S. Economic Growth. Applied Research in Economic Development 6(1) [žiūrèta 2011-10-03]. Prieiga per internetą: http://www.usm.edu/aredjournal/2009vol6no1_general_topics/ final_text/eastwood_2009_v6n1_testing_growth_theories.pdf

Fox, J. 1992. Democratic rural development: leadership accountability in regional peasant organizations, Development and Change 23(2): 1-36. http://dx.doi.org/10.1111/j.1467-7660.1992.tb00444.x

Fukuyama, F. 2001. Social capital, civil society and development. Third World Quarterly [žiūrèta 2011-11-08]. Prieiga per internetą: http://intranet.catie.ac.cr/intranet/posgrado/Met $\% 20$ Cual\%20Inv\%20accion/2008/Semana\%206/Fukuyama.pdf

Gold, S. J. 1995. Gender and social capital among Israeli immigrants in Los Angeles, Diaspora 4:267.301: 5-87.

Grootaert, C.; Bastelaer, T. 2001. Understanding and measuring social capital: a synthesis of findings and recommendations from the Social Capital Initiative, Social Capital Initiative Working Paper No. 24. World Bank, Washington DC, 4-14.

Grootaert, C. 1998. Social capital: the missing link, Social Capital Initiative Working Paper No. 3. World Bank, Washington DC, 2-17.

Grootaert, C.; Bastelaer, T. 2002. The role of social capital in development - an empirical assessment, in International Bank for Reconstruction and Development. 344 p.

Hanifan, L. J. 1916. The rural school community centre, Annals of the American Academy of Political and Social Science 67: 130-138. http://dx.doi.org/10.1177/000271621606700118

Juozaitienè, L. 2006. Socialinio kapitalo samprata ir komponentų tyrimas, iš Profesines studijos: teorija ir praktika, 55-63.

Knack, S.; Keefer, P. 1997. Does social capital have an economic payoff? A cross - country investigation, Oxford Journals Economics \& Social Sciences 112(4): 1251-1288 [žiūrèta 201111-15]. Prieiga per internetą: http://qje.oxfordjournals.org

Krishna, A.; Uphoff, N. 1999. Mapping and measuring social capital: a conceptual and empirical study of collective action for conserving and developing watersheds in rajasthan, India, Social Capital Initiative Working Paper No. 13. World Bank, Washington DC, 27-41.
Marginson, S. 2004. Bourdieu's notion of social capital. Monash University, Australia [žiūrèta 2011-09-25]. Prieiga per internetą: http://www.monash.edu.au/

Narayan, D. 1999. Bonds and Bridges: Social Capital and Poverty. World Bank, Washington DC, 6-13.

Narayan, D.; Pritchett, L. 1997. Cents and sociability: household income and social capital in rural Tanzania, in World Bank: Policy Research Working Paper, 871-897.

Onyx, J.; Bullen, P. 2000. Measuring social capital in five communities, The Journal of Applied Behaviour Science 36(1): 23-42. http://dx.doi.org/10.1177/000271621606700118

Palloni, A.; Massey, D. S.; Ceballos, M.; Espinosa, K.; Spittel, M. 2001. Social capital and international migration: a test using information of family networks, American Journal of Sociology 106: 1262-1298.

Portes, A. 2007. Social Capital: Its Origins and Applications in Modern Sociology. Department of Sociology, Princeton University, Princeton, New Jersey Australia [žiūrèta 201112-27]. Prieiga per internetą: http://digicult.net/moss_texts/ SOCIALCAPITAL_ItsOriginsandApplicationsinModernSociology.pdf

Putnam, R. 1993. Making Democracy Work: Civic Traditions in Modern Italy. Princeton, NJ: Princeton University Press, 46-104.

Putnam, R. D. 2000. Bowling alone: the Collapse and Revival of American Community. New York, NY: Simon \& Schuster. 19 p.

Sabatini, F. 2005. Social capital as social networks. A new framework for measurement. Working paper No. 83 [žiūrèta 201109-25]. Prieiga per internetą: http://ssrn.com/abstract=755065

Sabatini, F. 2006. The empirics of social capital and economic development: a critical perspective. FEEM Working Paper No. 15 [žiūrèta 2011-10-05]. Prieiga per internetą: http:// ssrn.com/abstract $=879712$

Social Capital: a review of the literature. 2001/10. Social Analysis and Reporting Division Office for National Statistics, 6-15.

Temple, J. S.; Johnson, P. 1998. Social capability and economic growth, Quarterly Journal of Economics 113(3): 965-990.

Tijūnaitienè, R. 2008. Socialinio kapitalo konceptas: dalyvavimo konceptas, Ekonomika ir vadyba: aktualijos ir perspektyvos 10(1): 186-192 [žiūrèta 2011-10-05]. Prieiga per internetą: http://www.su.lt/filemanager/download/6189/Tijunaitiene.pdf

Wallis, J.; Killerby, P.; Dollery, B. 2004. Social economics and social capital, International Journal of Social Economics 31(3): 239-258. http://dx.doi.org/10.1108/03068290410518238

Woolcock, M.; Narayan, D. 2000. Social capital: implications for development theory, research and policy, The World Bank Research Observer 15: 225-249.

http://dx.doi.org/10.1093/wbro/15.2.225

World development. 1996, Special Issue on Social Capital 24(6): 1119-1132.

Žiliukaitè, R. 2004. Socialinis kapitalas ir internetas, Sociologija. Mintis ir veiksmas 1: 104-114.

Ilona SKAČKAUSKIENĖ. Doctor of Social Sciences, Associate Professor, Head of Dept of Social Economics and Management, Vilnius Gediminas Technical University. Research interests: taxation, tax modeling and evaluating, social security, social and economic development.

Sigita BYTAUTE். Lecturer at Vilnius Gediminas Technical University. Research interests: social capital, private finances and banking. 